\title{
Letter from Ms. Lisa Henry, Secretary- General of the International Rehabilitation Council for Torture Victims
}

\author{
Lisa Henry*
}

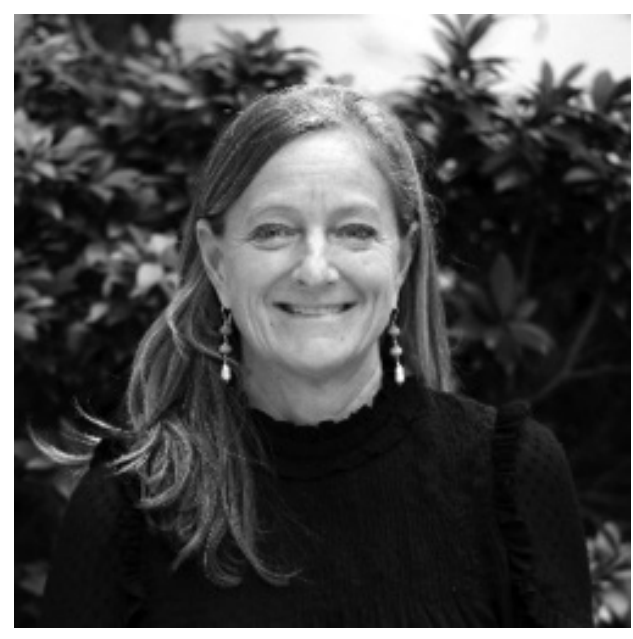

Transitioning into the role of Secretary General for the IRCT from a position in East Jerusalem as Country Director for Palestine was an interesting move. My previous work with rights-based humanitarian response was informed by the humanitarian principles of humanity, impartiality, independence and neutrality. Now in IRCT my work is with rightsbased rehabilitation for torture survivors as underpinned by the Right to Rehabilitation under the UN Convention against Torture and Other Cruel, Inhuman or Degrading

\footnotetext{
*) Secretary-General of the International Rehabilitation Council for Torture Victims Correspondence to: irct@irct.org
}

Treatment or Punishment (UNCAT, Article 14). The importance of having an international, rights-based policy framework to advocate for, in combination with results and knowledge from health-based experts, is essential to deliver the IRCT vision of "A World Without Torture".

My first-hand experience of the shrinking space for civil society organizations who are delivering lifesaving services while working creatively and persistently to gather and analyze data to influence decision and policy makers, equips me well for the job at IRCT. I know that we need to work efficiently and smart because of the challenging context in which our IRCT member centers operate. We need to share knowledge, inspire innovation and persistently pursue justice and holistic rehabilitation so that torture victims can become fully functioning members of society again.

The Torture Journal, started in 1991, is an important contribution by IRCT to the global knowledge platform for academics, practitioners and activists, as it gathers trend-setting data, articles and opinions with a significant scientific value. It is a reference source for professionals, a source of leading research in the field, and a forum for debate and knowledge exchange. Most recently the Torture Journal included articles and debate about forensic documentation 
of torture, sexual, gender-based torture, forced migration and sleep deprivation. The strategic selection of these timely topics has fostered an interdisciplinary, global learning community where young scholars, field practitioners, medical professionals and torture survivors can exchange views, and most importantly improve rehabilitative practices for torture survivors through new knowledge. The combination of research on medical, psychological and social impact of torture is unique to the Torture Journal.

In 2019 , I am proud that IRCT is delivering on its objective of a global rehabilitation knowledge platform thru publication of the Torture Journal. As we move into the year 2020 we will listen to the specific needs of our membership and community related to an innovative, relevant global knowledge platform to find the particular form that will support learning and debate up to the Tbilisi Scientific Symposium and IRCT General Assembly in October 2020 and also in the follow up and action points from that Symposium and GA. The 157 members in 75 countries and the wider anti-torture community have the right to relevant, timely knowledge which improves health practitioners ability to support torture victims to take control of their lives, be self-supporting and contribute to society.

Respectfully, Lisa Henry 